DOI 10.35694/YARCX.2019.46.2.014

\title{
ПРЕДПОСЕВНАЯ ОБРАБОТКА СЕМЕННОГО МАТЕРИАЛА В ЭЛЕКТРИЧЕСКОМ ПОЛЕ
}

\author{
В.В. Шмигель \\ д.т.н., профессор, профессор кафедры электрификации \\ ФГБОУ ВО Ярославская ГСХА, г. Ярославль
}

В настоящее время значение предпосевной обработки семенного материала и получение запланированных урожаев сложно переоценить. При этом основными приёмами такой обработки являются: воздушно-тепловой обогрев, применение химических протравителей и других агрохимикатов, затраты на применение которых довольно значительны. Результат же не всегда соответствует ожиданиям, особенно при неблагоприятных погодных условиях, не говоря уже об экологических рисках из-за применения пестицидов. Поэтому весьма актуальным является разработка новых экологически безопасных и экономически эффективных приёмов подготовки посевного материала, одним из которых является обработка семян в электрическом поле.

Автором разработан ряд машин для обработки семян электрическим полем [1, 2]. Промышленный образец МПОС3-100, изготовленный по разработке и чертежам В.В. Шмигеля (патент на изобретение РФ [2] получен в 2017 году), был представлен на международной выставке сельскохозяйственной техники AGROSALON 2016 и получил высокую оценку сельхозпроизводителей [3].

Цель исследования - оценить эффективность влияния обработки

Presowing seed treatment, electric field, crop productivity, yield семян в электрическом поле на продуктивность и качество сельскохозяйственных культур.

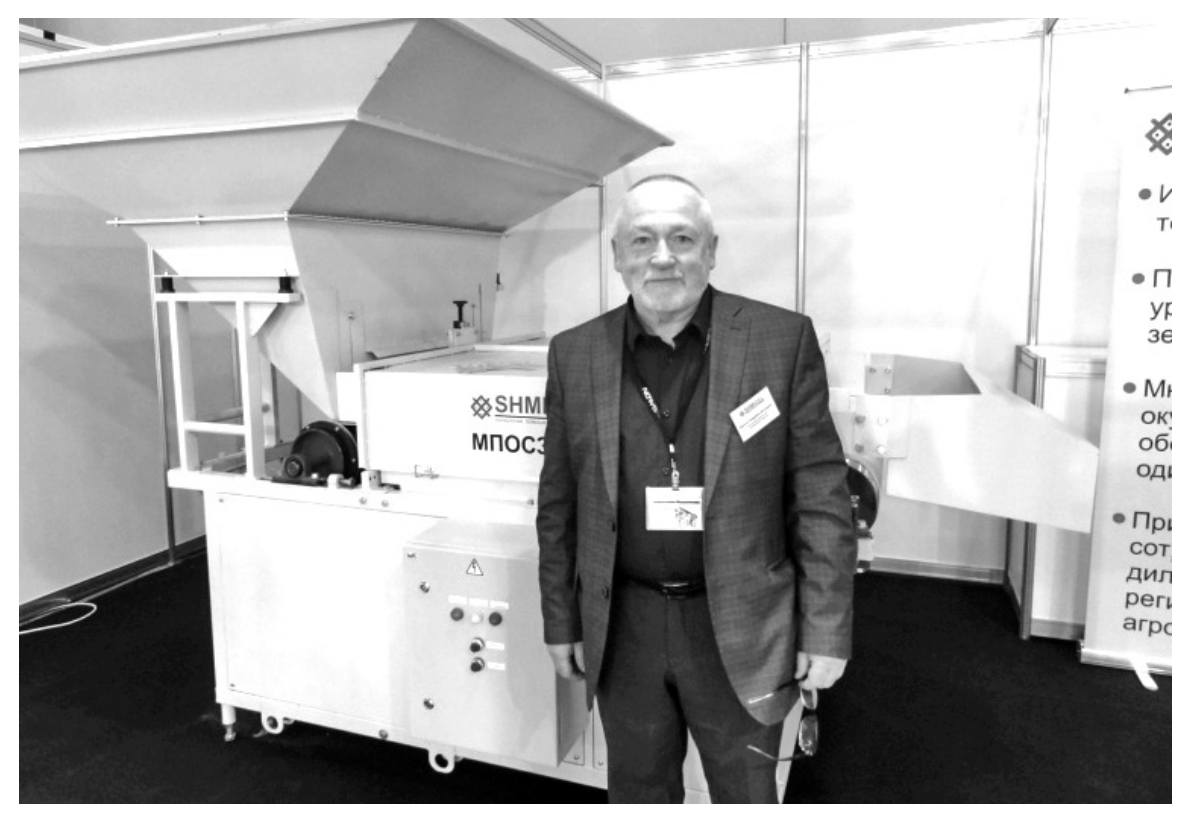

Рисунок 1 - Разработчик МПОСЗ-100 В.В. Шмигель и общий вид машины 
Задачи исследования - проведение фенологических наблюдений за сельскохозяйственными растениями, определение полевой всхожести и густоты стояния растений, учёт динамики роста растений по фенологическим фазам, учёт засорённости сельскохозяйственных культур сорными растениями, определение величины и структуры урожая.

Для предпосевной обработки использовалась установка «Ленточный электрический многослойный стимулятор семян» (ЛЭМС), имеющая патент на изобретение [1]. На рисунке 1 показан общий вид установки, расположенной в учебной лаборатории кафедры электрификации ФГБОУ ВО Ярославская ГСХА.

Суть способа обработки семян заключается в том, что благодаря стимулирующему действию электрического поля на клетки семян ускоряются биохимические процессы обмена веществ, мобилизуются защитные реакции в семенном материале [4]. Кроме этого на верхнем слое семян, за счёт большой напряжённости поля в малом воздушном промежутке, большое их количество ориентируется вдоль силовых линий поля, в результате чего образуется положительная корона, и через весь слой стекают с ориентированных

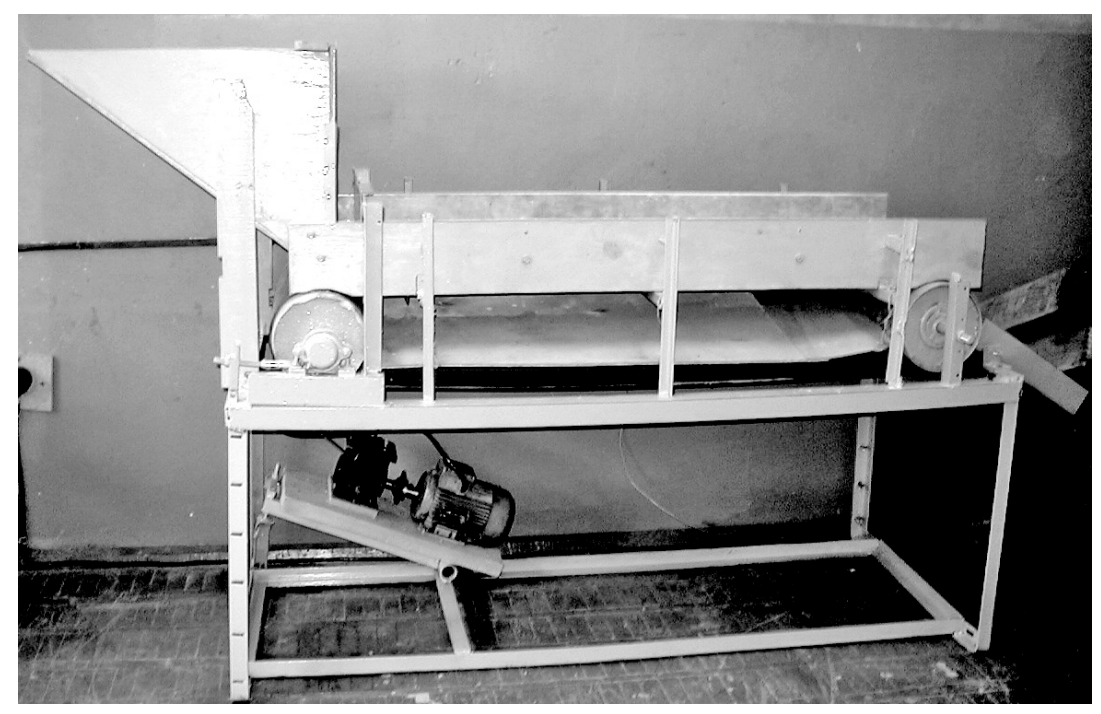

Рисунок 1 - Общий вид ленточного электрического многослойного стимулятора семян

семян отрицательной полярности аэроионы, которые уничтожают болезнетворные бактерии и грибковую микрофлору, находящиеся на семенах в слое, который подвергается обработке [5].

С целью проверки эффективности данного приёма проводились лабораторные испытания для установления оптимальных параметров обработки семян, а также в 2015 году был заложен трёхфакторный полевой опыт на опытном поле научно-исследовательской лаборатории ресурсосберегающих технологий в земледелии академии (Ярославский район, д. Бекренево) на дерново-подзолистой среднесуглинистой почве (как наиболее распространённой в Ярославской области) при использовании яровой пшеницы сорта «Дарья».

Для возможности дальнейшего использования результатов исследования в сельскохозяйственных предприятиях разного уровня материально-технического и финансового обеспечения, кроме фактора «Обработка семян в электрическом поле», рассматривались и такие, как: «Система удобрений» и «Обработка бактериальными удобрениями (биопрепараты)».

Схема трёхфакторного опыта:

Фактор 1 - обработка биопрепаратами, «О»:

1. Без биопрепаратов, « $\mathrm{O}_{1}$ ».

2. С обработкой биопрепаратами, «О $\mathrm{O}_{2}$.

Фактор 2 - система удобрений, «У»:

1. Без удобрений, «У,

2. Полное минеральное удобрение в нормах $\mathrm{N}_{95} \mathrm{P}_{15} \mathrm{~K}_{95}(1$ фон $)$, « $\mathrm{Y}_{2} »$.

3. Полное минеральное удобрение в нормах $\mathrm{N}_{250} \mathrm{P}_{75} \mathrm{~K}_{200}(2$ фон $)$, « $\mathrm{Y}_{3} »$.

Фактор 3 - обработка семян в электрическом поле, «Т»:

1. Без обработки, «Т 1 ».

2. С обработкой в электрическом поле, «Т 2 ».

Опыт был заложен методом расщеплённых делянок с рендомизированным размещением ва- 
риантов в повторениях, повторность опыта трёхкратная. Всего вариантов в повторении 12. Площадь элементарной делянки (делянки третьего порядка, «Т») составила 21 м² (7 м x 3 м), площадь

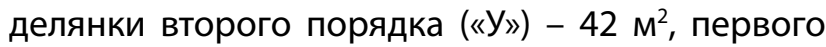
порядка («О») - 126 м². Общая площадь опыта $378 \mathrm{~m}^{2}$.

В опыте использовались стандартные для региона технологические приёмы возделывания яровой пшеницы, кроме изучаемых. Какие-либо пестициды не применялись. Нормы минеральных удобрений рассчитывались на планируемую урожайность. Все наблюдения, полевые и лабораторные исследования проводились согласно общепринятым методикам по показателям развития и продуктивности культурных растений (фенологические наблюдения, полевая всхожесть и густота стояния растений, динамика роста растений по фенологическим фазам, засорённость сорными растениями, величина и структура урожая), для выявления достоверного влияния изучаемых факторов на исследуемые показателя использовался дисперсный анализ.

По результатам проведённого исследования [6] можно сделать следующие выводы:

1. Обработка семян с применением ЛЭМС способствует достоверному увеличению густоты стояния растений яровой пшеницы на 26,1\% в сравнении с вариантом без обработки.

2. На вариантах, где семена пшеницы подвергались обработке в электрическом поле, отмечено существенное снижение общей численности сорных растений на 29\% и уменьшение их сухой массы на 56,5\%. Это явилось следствием хоро- шего развития растений яровой пшеницы как на начальном этапе, так и в течение вегетации, обеспечивающего повышение их конкурентной способности по отношению к сорнякам.

3. Динамика показателей структуры урожая под действием фактора 3 была следующей: средняя высота растений - показатель, который в меньшей степени подвергся изменению, однако тенденция его увеличения на вариантах с применением электрического поля прослеживается (в среднем на 3\%), количество продуктивных стеблей существенно увеличилось (на 29,3\%), такое же положительное действие обработки семян с применением ЛЭМС наблюдалось по среднему количеству зёрен в колосе, увеличение составило 19\%, а также по средней массе зёрен в колосе (увеличение на 17\%).

4. В среднем по изучаемым факторам обработка посевного материала в электрическом поле позволила получить достоверное увеличение урожайности зелёной массы на 15,9\%.

5. Благодаря существенно более высокому количеству зёрен в колосе и повышенной их массе (на 17\%), биологическая урожайность зерна яровой пшеницы достоверно увеличилась при использовании в качестве метода обработки семян электрического поля на $34 \%$.

6. Установлено положительное действие обработки семян яровой пшеницы в электрическом поле на следующие показатели: полевую всхожесть (увеличение на 2,5\%), продуктивную кустистость (увеличение на 3,2\%), среднюю высоту растений (увеличение на 3\%), площадь листовой поверхности растений (увеличение на 11,3\%).

\section{תumepamypa}

1. Пат. 2181234 Российская Федерация, МПК А01С/00 Машина для предпосевной обработки семян в электрическом поле [Текст] / Шмигель В.В., Ниязов А.М.; заявитель и патентообладатель «Костромская государственная сельскохозяйственная академия». - № 99118792/13; заявл. 30.08.1999; опуб. 20.04.2002, Бюл. № 11.

2. Пат. 2632917 Российская Федерация, МПК А01С1/02 Машина для предпосевной обработки семян в электрическом поле [Текст] / Шмигель В.В., Шмигель Д.В.; заявитель и патентообладатель Шмигель В.В., Шмигель Д.В. - № 2016122765; заявл. 08.06.2016; опубл. 11.10.2017, Бюл. № 29.

3. Инновационный способ предпосевной обработки семян в электрическом поле [Текст] // Аграрные известия. - 2016. - № 10 (117). - С. 72-74.

4. Шмигель, В.В. Сепарация и стимуляция семян в электрическом поле [Текст]: монография / В.В. Шмигель. - Кострома: Изд-во КГСХА, 2003. - 233 с.

5. Пат. 2182411 Российская Федерация, МПК А01С1/00 Способ предпосевной обработки семян в электрическом поле [Текст] / Шмигель В.В., Ниязов А.М.; заявитель и патентообладатель «Костромская государственная сельскохозяйственная академия». - № 991118786/13; заявл. 30.08.1999; опуб. 20.05.2002, Бюл. № 14.

6. Труфанов, А.М. Эффективность предпосевной обработки яровой пшеницы в электрическом поле [Текст] / А.М. Труфанов, А.А. Мягтина, В.В. Шмигель, Т.П. Сабирова // Вестник АПК Верхневолжья. - 2016. № 2 (34). - C. 31-35. 


\section{References}

1. Pat. 2181234 Rossijskaya Federaciya, MPK A01S/00 Mashina dlya predposevnoj obrabotki semyan v elektricheskom pole [Tekst] / Shmigel' V.V., Niyazov A.M.; zayavitel' i patentoobladatel' "Kostromskaya gosudarstvennaya sel'skohozyajstvennaya akademiya». - № 99118792/13; zayavl. 30.08.1999; opub. 20.04.2002, Byul. № 11.

2. Pat. 2632917 Rossijskaya Federaciya, MPK A01S1/02 Mashina dlya predposevnoj obrabotki semyan v elektricheskom pole [Tekst] / Shmigel'V.V., Shmigel'D.V.; zayavitel'i patentoobladatel'Shmigel'V.V., Shmigel'D.V. № 2016122765; zayavl. 08.06.2016; opubl. 11.10.2017, Byul. № 29.

3. Innovacionnyj sposob predposevnoj obrabotki semyan $v$ elektricheskom pole [Tekst] // Agrarnye izvestiya. - 2016. - № 10 (117). - S. 72-74.

4. Shmigel', V.V. Separaciya i stimulyaciya semyan v elektricheskom pole [Tekst]: monografiya /V.V. Shmigel'.Kostroma: Izd-vo KGSHA, 2003. - 233 s.

5. Pat. 2182411 Rossijskaya Federaciya, MPK A01S1/00 Sposob predposevnoj obrabotki semyan v elektricheskom pole [Tekst] / Shmigel' V.V., Niyazov A.M.; zayavitel' i patentoobladatel' "Kostromskaya gosudarstvennaya sel'skohozyajstvennaya akademiya». - № 991118786/13; zayavl.30.08.1999; opub. 20.05.2002, Byul. № 14.

6. Trufanov, A.M. Effektivnost' predposevnoj obrabotki yarovoj pshenicy $v$ elektricheskom pole [Tekst] / A.M. Trufanov, A.A. Myagtina, V.V. Shmigel', T.P. Sabirova // Vestnik APK Verhnevolzh'ya. - 2016. - № 2 (34). S. 31-35.

\section{ОБЫЯВЛЕHИЕ}

В ФГБОУ ВО Ярославская ГСХА в 2019 году издано электронное учебно-методическое пособие в двух частях

\section{«ЭЛЕКТРОСНАБЖЕНИЕ»}

\section{Авторы В.В. Шмигель, А.С. Угловский \\ 2 электрон. опm. диска (CD-R)}

В учебно-методическом пособии рассмотрены общие вопросы электроснабжения, представлены виртуальные лабораторные работы по дисциплине «Электроснабжение», разработанные в соответствии с программой курса для студентов бакалавриата по направлению «Агроинженерия», профиль «Электрооборудование и электротехнологии в АПК». Излагаемый материал сопровождается примерами и программами в Simulink, существенно облегчающими освоение курса электроснабжения.

Учебно-методическое пособие предназначено для студентов аграрных высших учебных заведений.

УДК 621.318; ББК 31.26; ISВN 978-5-98914-207-1

ПО ВОПРОСАМ ПРИОБРЕТЕНИЯ ОБРАЩАТЬСЯ ПО АДРЕСУ:

150042, г. Ярославль, Тутаевское шоссе, 58, ФГБОУ ВО Ярославская ГСХА e-mail: e.bogoslovskaya@yarcx.ru 